\title{
私の図書館人生
}

\section{Passages from My Library Life}

\author{
今 村 慶之助* \\ 麻布大学附属図書館
}

\section{I .はじめに}

本誌加ら “60年代”をテーマに寄稿をむとめら れ，私は既に国立大学を定年退職した身であり， やや戸惑ったが “世代間のアイデアを継承したい” という編集委員会からのお勧めにしたがい拙文を 寄せることとした。アイデアと言うほどではない が私も60年代を体験した者の一人として，ささや かな体験の一部とその体験を通じて，その後の図 書館活動をどのように見ているかなど, 感想程度 のことを述べさせていただく。

\section{II. 私の体験}

私が医学図書館にお世話になったのは，昭和 34 （1959）年東大医学図書館への就職にはじまる。 したがってやや荒々しいが進歩の覇気に満ちた60 年代は私に初心を植え付けた年代であるといえる。 “鉄は熱いうちに打て”の言葉どおりに，近代的 な医学図書館の創設を志向したこの年代の図書館 に身を置き，その熱気を全身に浴びることになっ た。その体験が私の内に図書館員としての使命感 を育てたことを強く感じている。図書館先進国と 言われる国々においてす第二次世界大戦後の復興 の波の一環として図書館振興策がとられ，60年代

\footnotetext{
* Keinosuke IMAMURA : Library, Azabu University. 1-17-71 Fuchinobe, Sagamihara 229, Japan.
}

（1991年6月25日 受理）
は世界的に近代的な図書館に飛躍した時代といわ れる。わが国の図書館界においてもその流れの中 で,これらの国々からの支援を受け, 近代的な図 書館学の方法論を学び，また図書・資金などの援 助むうけた。医学図書館においては米国のCMB (China Medical Board of New York, Inc.) か らの援助が特筆される。

多くの医学図書館がその恩恵に浴したが, 東大 でもこのCMBの寄贈を受け, 現在の医学図書館 を建設した。私がここで述べたいのは，このCM Bが寄付の条件として東大医学部へ示した提言に ついてである。その要旨は次のようであった。

1. 独立棟であること。

2 . 当座必要な参考図書を除き, 全ての図書を中 央化すること。

3 . 学部の職員として教授会に出席し, 発言しう る資格を有する, 訓練された司書によって指揮 運営されること。

4. 書籍も雑誌む, いずれす学生す使用しうるよ うに運営すること。

(1) 放課後数時間は開館すること。

（2）学生の使用にとむないその世話をする十分 な職員をもつこと。

（3）学生の使用のための場所を提供すること。 5. CMBは建物ならびに内部施設にたいし50： 50の比（同額）で25万ドルまでの寄付を考慮する。 この提言は東大医学部がこれらの諸項目を実行 することにより，その成果としての近代的な図書 館サービスが広く国内に普遍し, 日本の医学の進 歩に寄与したいとするものであった。当時の東大 
の多くの学部はこのいずれの項目にも当てはまる ところは少ない旧態依然とした状態であり，医学 部あ多くの図書・雑誌が教室等に分散した古い体 制のもとにあった。しかし学内においては図書館 員はもとより，学生・教員などからも学術や社会 の進歩に沿った図書館サービスへの改善が強く求 められており，医学部においてあその改善の気運 は徐々に醸成されつつあったと思われる。したがっ てこの提言の第 5 項目に示す50\%（25万ドル： 9,000万円）の学部側の負担金の拠出についても, 自助的な革新への意識か改善の鍵としてはたらき, その実行を促したあので，CMBの他大学等への 援助においても，この自助を促す同様の方法によ り，単に建物の寄贈に止まらず，基盤整備として 図書館システム全体の改善を求めたものである。

戦後加ら60年代にかけての外国からの援助の一 つに留学を挙げなければならない。その多くは米 国への留学であったが，研究者と共に多くの図書 館員がCMB等の奨学金を得て外国へ渡り, 近代 的な四書館活動についての知識と体験を身につけ て州国した。

各大学の図書館報等に利用者の声として，外国 の図書館の見聞記がよく収載されている。その記 事の多くは外国の図書館サービスへの賛辞と日本 のそれへの慨嘆の記であると言えないこともない。 戦後すでに半世紀を経ようとしている。そして日 本は世界の経済大国と言われている。いつまであ “外国の図書館”でああるまいとの想いは誰の胸 にああることではあるが，CMBの提言を今日的 な視点で見たときに日本の大学困書館の進歩のい かに遅々たるあのであるかを認めざるをえないの ではないか。多くの図書館員が外国に渡り, 近代 的な図書館学を日本に導入した。むちろん, 多く の面での進歩はあったが，その後半世紀近い歳月 を経たにあかかわらず，米国などの図書館システ ムの中で日本が学ぶべき基本的なあのがどうして あ日本に移植できないのは何故か。60年代の指導
者 Dr. Brodman は日本を訪れた際“日本の図 書館は米国より10年遅れている"と言ったが，30 年を経た今日の両者の格差が縮まらないことにつ いて，サービスを受ける側に対して私共は責任を 感じなければならないと思っている。

21世紀は情報化社会・生涯学習社会之言われる。 図書館の雑誌などにも未来志向の明るい展望をつ づる記事も多い。私も情報の価值が高まり, 社会 への影響力か強まるであろうし，多様な学習機会 を人々は求めるであろう，その方向は誤りなく進 むと信じている。生涯学習をめざす社会はまさに 図書館の出番，追い風を感じるが，座して僥倖を 待つ環境にはないような気がする。何が問題なの か考えてみよう。

\section{III. 図書館活動の姿について}

現在の図書館活動は60年代の大きな発展に支え られていることは言うまであない。ソ連のスプー トニク（1957）に始まる米ソの宇宙競争は科学の 巨大技術のスタートをわれわれに強く印象づけた。 LCの MARK Project（1961）のニュースは図書 館と情報の結び付けを自然なむのにした。医学に おいては NLM の MEDLARS（1962）による INDEX MEDICUS が私どあのてもとに届いた。 そして私達は東大で TOSBAC 3400 を使って雑 誌システムの電算化（1963）にとりかかった。こ のような最新の科学技術に導かれた図書館活動の 斬新な姿に，図書館員の誰しもが夢を託したこと は間違いない。しかし私は電算機による革新的な 作業に熱をあげながらあ，これが利用者によ゙れだ け便利になるのかとの想いは，頭のどこかに微か ながらああったような気がする。やがて歳を重ね るにしたがい図書館活動の見方む変わり，その思 いは高まり, 問題の解決を阻むものを身近かに感 じ，その時どきの職務のなかで，その解決に努め たが“道なお遠し”の感が深い。ここで私見のい 
くつかを取り上げてみたい。

その 1 は蔵書についてである。私が若い頃読ん だ蔵書構築についての論文の中で High value low use という言葉に会い, 今であ新鮮な印象 が残っている。その頃蔵書論に Core と言う言 葉が流行していた。Core journal など利用度の 高い雑誌などの評価が盛んに行われていた。ブラッ ドフォードの法則などが影響したのかむ知れない。 また医学図書館は雑誌依存が大きいので利用率の 高い雑誌の影響に研究が傾くのは自然であった。 しかし，精選された High value low use 資料 を利用者に保証すべき図書館の責任を私も感じ始 めていたが，日本の図書館界は一般的に蔵書構築 の視点が弱く，その中で私どもむこれを図書館活 動の重要な一環として育てる努力を怠ったために, Weeding など蔵書の質を高める活動が定着せず, 日本の図書館活動の可能性を著しく弱めていると 残念に思っている。その頃東大の医学図書館に医 学中央社から抄録に使用後の雑誌が寄贈されてい た。それらを書架に繰り込みながら, 医学研究の 幅の広さに目を見張ったものである。図書館員が 図書の選択権を持たない限り Low use 資料の収 集は難しい。かつて東京での世界医学図書館会議 の,この図書選択のテーマの場で, 自らが医学者 であある日本のある医学図書館長が “医者ではな い司書が医書を選択できるのか” と発言し, 議長 から“司書は図書の専門家である”といなされた ことがあった。

米国の図書館には伝統的に良書選定の精神があっ たと言われる。フロンティア精神に通じるライブ ラリアンシップを育て，支えてきたものの大きな 部分にこの良書普及の使命感があったと思う。し かし米国においても大学では，この図書選択権が かつては教員にあり，それが図書館員に移る過程 において, 両者の戦いの歴史があり, 選書権に代 表される図書館員の専門性の主張が社会に受け入 れられ，その結果として現在のバランスのとれた
蔵書構築がシステム化され，また図書館員の資質 向上にも大きく寄与したと推察される。有名な Farmington plan などの共同収集システム, USBEなどの寄贈交換システムなどは選書の主役 が図書館員であればこそ生まれたもので，個別の 各図書館が用いる図書館員の専門性を発揮せしめ る選書システムとリンクし, 補完しあいつつ精選 された無駄のない集書が行われている。

日本で共同収集や寄贈交換システムが医学図書 館を除いて育たないのは, 選書権が図書館員に無 いことによるのは明らかで，それによる有形無形 の損失は計り知れない。現在の図書館を取り巻く 環境の中で, 1 図書館ではどうにもならないこと が多いが, その中で特色ある蔵書構築などは図書 館間の共同収集・寄贈交換などの支援システムが ないとできるすのではない。私は東大時代に裏田 武夫先生の指導による USBE などとの寄贈交換 業務を学んだ。実際の作業は青木孝雄, 早川英子 両氏が主に当たったが，その注がれた膨大なエネ ルギーと果実の貴さに感銘を受けた。このような 共同収集・寄贈交換システムが日本に必要として 生まれたのが医学図書館の交換制度で, 今後の発 展と各分野に広がることが期待される。

選書権が図書館員に無い限り, 精選された蔵書 構成はできないし, 図書館員の資質の向上む期待 できないとの思いから，筑波大学在任中に教官当 積算校費の $1 \%$ の図書費を要求して認められた。 発足（1979）当時は約 2,500 万円/年で，これを 「新刊和書購入費」と称して, わが国で刊行され る学術図書を図書館員のみによる選書によって購 入することにした。毎月 200 万円程, 和書に限る とはいえこれの選択に当たる職員の経験と図書の 集積の意味は大きい。私は 5 年たったら教員の図 書館を見る目が変わるのではないかと期待した。 勿論, 図書館員のみによる選書が望ましいわけで はない。教員の学術分野について専門家としての 意見や書店員の出版にかかわる専門的知識と, 図 
書館員の専門性との, この 3 者の協力が得られた 時こそ真の選書が果たされるであろう。筑波大学 の選書システムは, 教員の側に過度に傾いた選書 のポールを図書館の側に引き戻したものである。 私の在任中に和書が充実してきたとの感想や, 洋 書もこの方法で買ってほしいとの声も聞いたので, 図書館の努力がそれなりに評価を得ていると思う。

今後情報の価值が高まるにしたがい，収集する 情報の質が問われ，その選別をする選書システム の機能が一層重要になる。大学図書館においては その蔵書数が何十万, 何百万冊之言ってみても, その内容は規模が大きくなるにしたがい, 著しい 重複と偏在によって積まれた脆弱なむのであるこ とを直視することが今後のために大切なことであ る。蔵書構築はどの面からみても図書館の高い総 合力が必要で, 集中化・共同収集など, 学内学外 を問わず幅広い協力支援を受けることのできる体 制が望まれる。

最近，中央教育審議会の報告に関わる記事が新 聞などに散見されるが，そのなかで大学の図書費 の少なさを嘆く記事が目を引く。しかし本当は図 書費の少なさより使い方が問題である。文部省の 統計" と米国のそれ2)を比較すれば明らかなこと であるが，日米の大学図書館の図書費の比は，教 員之学生を含めて 1 人当たり約 $22,000 円: 11,000$ 円 (1985), 日本は $2 ： 1$ の割合で多い。最近米 国からは予算削減など暗いニュースを聞くが，集 書について協力度の高い米国の大学図書館は, 逆 境への適応性は日本より格段之高いと思われる。 この少ない予算で素晴らしい蔵書を生み出すシス テムが, 日本でどうにあ育てられないものの一つ である。

その 2 は時間外開館についてである。私は1968 年にCMBの資金で渡米し, 多くの大学図書館等 を見学した。ワシントン大学 (St.Louis) に 4 カ 月間帯在したが，その間に図書館が夜12時まで開 館していたので, 閉館の少し前に入館しその様子
を見学したことがあった。在館者は多くはなかっ たが，それであちらほらと研究者や学生が読書を しているのが見られ，その真摰な学習の姿に私は 深い感銘をうけた。私は口の中で “これが図書館 だ”と呟いていたその時の情景をいまでも忘れる ことができない。私は筑波大学図書館の創設に際 し, 夜間開館を重点事項として夜10時までの開館 を実現した。時々閉館の前に館内を歩き回り，か つてのワシントン大学の様子を重㸚わして想い, また図書館のエネルギーを肌に感じて職務につい ての責任の重さと，それを多少なりとあ果たした との思いを覚えたすのである。日米の大学図書館 の開館時間を数字として表すことは難しいが, 米 国の University と言われる大学では, 年間の開 館日が360日, 朝 9 時から夜12時までというとこ ろが多い。週休二日制が徹底している米国におい てである。

私達は日本であ安定的・普遍的なシステムとし て，このような夜間・休日開館ができるようにす ることが社会の期待であり，図書館活性化の鍵で あることを念頭におき，真剣に取り組まなければ ならない。

「いつであ だれでも どこであ」は日本の図 書館界のテーゼである。「いつであ」開かれてい る図書館にすることが米国のようにできないのは, 日本と米国とでは異なるところがあるのかすしれ ない。米国では学生はよく勉強しないと卒業でき ないし，教員は激しい競争に曝されているので， それぞれよく図書館を利用すると言われる。確か にそれぞれ事実に違いないが, 私は米国の図書館 員のニーズに応えようとする積極的な姿勢, 職務 にたいする使命感が支えているように感じている。 図書館はニーズに応えることによって機能する施 設である。図書館のテーゼ「いつであ」はニーズ そのものと言ってよい。

図書館の利用者は常連のように頻繁に顔を見せ る少数の人, ときどき来館する人たち，たまにし 
か図書館には来ない多数の人々から成る。どのグ ループに属していても，来館したときには同じよ うに満足が得られなければならない。そこが難し い。図書館員も人間だから常連とは親しくなって, とかく過剰サービスあいとわない。滅多に来ない 人之は人見知りして，機械的な反応に陥りやすい。 常連の人たちは図書館の実態をよく知っているの でその範囲内で要領よく利用し，時間外開館など は求めない。利用頻度が少ない人ほど図書館の事 情に疎く，満足の範囲も宧减し疎外感を受けやす い。しかもこのような利用の少ない人々が利用者 層の大多数を占めるところに問題の本質があり， このような利用の少ない人々の求めるものに応え るには「いつでも」の要件をできるだけ満たすこ とが望まれる。

その 3 は図書館員についてである。私は大学で 図書館学を専攻し実務についた。卒業生達の中で, 図書館の実務についた人たちの多くは縁の下の力 持ちで，日の当たらない立場の人が多いように見 受けられる。長年専門分野で精励し業績を積まれ た人が，その評価を得て図書館長となり，抱負経 綸を発揮されて後進の指導に当たるのが世間の在 るべき姿ではないか。大学においても事務長など は他の分野の人の処遇に使われ，図書館員の昇進 が阻まれる。国立大学では図書館の部制が整備さ れるに従い，他の職制と共に管理職に途用される 道は開かれているが, 後進性は依然残っている。 まして CMB の提言にある“訓練された司書” が大学図書館長の地位に就くことは，現今の状況 ではとても考えられない。専門職員の専門的知見 を遺憾なく遂行する道が閉ざされていることは， 図書館員の不幸のみならず，このサービスを受け る側からみてあまことに残念なことと言わざるを 得ない。また社会の健康な発展のためにも好まし くない。しかしその改善を図るには，現在の図書 館の姿を正確に把握し，その職責にある図書館員 が職務の遂行を通じ社会の共感を得て道を拓く以
に展望は見出だせないと強く感じている。 中根千枝説 ${ }^{3}$ によれば「日本社会は情緒に基づ くタテ型社会で, 合理主義・契約精神の根付いた 欧米と異なり，社会を横断的に結ふ職能別組合よ りは, タテ型の企業別組合になり，組織を超えた 移動を妨げる。その結果能力よりはグループ内の 人間関係が重視され，能力に基づく専門家の育成 を困難にする」と言う。このような社会構造の運 動法則の下に, 学校間とか企業間の並立する, 孤 立的な集団間の競争が展開される。ここに日本企 業の効率が生まれる秘密があり，和とか序列など 日本的な目に見えない人間関係により，厳しい環 境に耐える秩序が維持される。このような連帯性 の少ない大小の集団は，その運動を高めようとす るとき，行政組織への依存度を高め，その指導に 敏感になる。そのため図書館のような専門機能の 独立性を維持することが後退する。公共図書館が 地方自治体行政の強い統制の下にあり，また図書 館間の自主的な向上心による異動の機会を得るこ とが困難など我々が日々体験しているところであ る。日本の図書館界をその視点加ら見ると，図書 館員としての専門家の育成がかなり困難な社会で あると言えよう。このことをしっかりと念頭にお かなければならない。このような社会的な制約を 克服して明るい展望をあたらす方策を見いだすこ とができるか。

最近社会的に重要な職業として, 看護婦さんの 養成と処遇の問題が報じられている。昼夜の別な く24時間体制で過酷な勤務に耐えるには，たんに 待遇の改善だけでは勤まるものではないと思う。 数年にわたる体系的な専門教育の下に，看護婦と しての職業的な使命感が育てられ，職務の遂行を 支えているすので，他の社会的に重要な専門性を 必要とする職務に共通する。学校の先生にしてあ お巡りさんにしても，ほとばしるような熱い奉仕 の発露に触れたときに，私共は感謝と敬意を感じ る。近年の公共図書館の素晴らしい発展は, 貸出 
を基本においたサービス重視の活動が地域住民の 熱い支持を受けたあので, 図書館活動の今後に明 るい展望をもたらすと共に, 看護婦さんに劣らず 高い専門性と強靱な精神力を要する図書館員とし ての専門職集団の可能性を見る思いがする。

しかし専門性を疎外する社会的要因を抑制し， 図書館の発展を確かにするには, 全ての館種が団 結し，社会に対しその存在感を高めなければなら ない。それには人事の視点を図書館の設置母体内 のタテ型社会から，図書館間を結ぶ横断的な專門 職業集団に移すことで，そこから具体的な対策が 考えられるであろう。その中の一つとして公共図 書館の今後の最む重要な課題として専門職の館長 を増やすことがある。大学図書館であ同じことで はあるが，それぞれの図書館が抱える問題を解決 するために専門職による管理運営が必要であるの みならず，また社会的にも図書館の館長は専門職 でなければならないとする認識が定着しなければ ならない。大学では当分無理としても公共図書館 では法律の支えもあり，図書館界が一致団結して 進めば道は開けるのではないか。これの停帯から 脱却するために図書館界は，その準備や支援体制 について今一歩の努力が必要と思われる。その意 味でこの館長問題は特に全ての館種の指導者及び 図書館情報学を担当してる教員の協力が求められ る。教員が教育・研究と共に実務を行うことは, 医学者が教育・研究・臨床をともに実践すること と同じであり, 館長としての人材をうるために, さらには教育と実務との間の人の交流による人材 の育成の観点から，また図書館学の発展のために あ今後の図書館界の重要な努力目標であると思う。

\section{IV.これからの図書館について}

臨教審から中教審, 大学審へと大学改革の提言 は数多く出されたが, 東大を頂点とする競争のな い序列構造は当分摇るぎそうもないし, 教育の中
味を問わず, この序列に連動した学生の就職シス テムは，日本特有の効率の良い新卒者市場として 機能しているので, 大学改革のインセンティブは はかなく弱いように見える。しかし大学は子供の 数の減少など社会基盤の変動に圧され“社会にお ける大学の在るべき姿”を模索し始めた。大学は 社会と連動して大きく動こうとしている。その中 にあって図書館は真に大学の教育研究支援の体制 が組み立てられるか，重大な局面に在ると言えよ う。図書館は社会との接点にあり, 社会の今後の 在り方を示す生涯学習・情報化・国際化などの指 標は, 未来志向型の図書館活動に潜む本質的な願 望と言えなくむない。知識は大学の占有物ではな く社会との共有の資産であるとし今後を見つめる ならば, 我々の進む道は医学とか大学の枠をさら に広げ，図書館という共通の働きの下に団結し， その可能性を高めることにあることは誰の目から みてあ明らかなことではないか。

図書館は文化の創造を支えるパイオニアの覇気 が要る。本来サービスには旧いあのより新しいも のへ移そうとする創造的な姿勢が無いとサービス にならないところがあり，規則の内側を遵守する 官僚性に染まるのを避けなければならないが，こ こが日本的な弱みかす知れない。指導者はこのあ たりを十分に踏まえて舵取りをすべきで, 図書館 員の日頃の苦労が報われるようにするためにもう 少し工夫するところがあるのではないか。図書館 員の願望を集約するためには，その一つは図書館 員の一人一人が日本図書館協会の個人会員として 入会し，一つにまとまるように導くことである。 医学図書館とか大学図書館とかは機関の活動であっ て, 個人としてはJLAの会員であるのが図書館員 のコンセンサスとなるべきである。“急がばまわ れ”というがこれが徹底すれば，図書館界の前途 にかなり明るい展望が開けるのではないかと思う。 


\section{V. おわりに}

私にとって60年代は新人の年代であったが，こ の頃を回顧するとき先ず思い出されるのが，多く の熱心な図書館員の方々の面影である。医学図書 館は大学の中で, その活動も職員の意識もやや孤 立的であるが，ほかに見られない幅広い活動がで きたのは，これらの方々が恵まれない環境の中で JMLAの組織を強化し, 医学図書館員としての専 門集団の活動の場を守り育ててきたことによるも のである。今後はこの道をさらに広げ，他分野と の協力を強めることにより，これからの図書館員
の皆さんが自分の職務が社会を改革し，創造性の ある活力に満ちた新しい時代に導くのだとの強い 確信をむって進まれることを心から願っている。

\section{参考文献}

1) 昭和62年度大学図春館実態調查結果報告 文部省, 1988.

2) Higher Education General Survey-College and University Libraries, Fall 1985, (HEGISXX) ALA 1987.

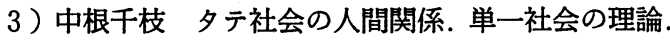
講談社, 1967. 